\title{
Organizational Citizenship Behavior Ditinjau dari Komitmen Orgnisasi pada Guru di Sekolah Swasta Methodist-2 Medan
}

\section{Organizational Citizenship Behavior Judging from the Organizational Commitment to Teachers at the Medan Methodist-2 Private School}

\author{
Jessica Yustan*, Diny Atrizka \& Achmad Irvan Dwi Putra \\ Program Studi Psikologi, Fakultas Psikologi, Universitas Prima Indonesia, Indonesia
}

Diterima: Mei 2019; Disetujui: Juli 2019; Dipublish: Agustus 2019

*Coresponding Email: iessicavustan@gmail.com

\begin{abstract}
Abstrak
Penelitian ini dilakukan untuk menemukan hubungan antara komitmen organisasi dengan organizational citizenship behavior (OCB). Hipotesis dalam penelitian ini adalah ada hubungan yang positif antara komitmen organisasi dengan organizational citizenship behavior (OCB). Subjek penelitian yang digunakan dalam penelitian ini adalah guru yang bekerja di Sekolah Swasta Methodist-2 Medan sebanyak 110 orang dipilih dengan metode purposive sampling. Data diperoleh dari skala untuk mengukur OCB dan komitmen organisasi. Analisis data yang digunakan adalah menggunakan PearsonProduct Moment Correlation melalui bantuan program SPSS 20.00 for Windows. Hasil penelitian ini menunjukkankorelasi sebesar $0.388(\mathrm{p}<0.05)$ dan menunjukkan adanya hubungan positif antara komitmen organisasi dengan OCB. Hasil penelitian ini menunjukkan bahwa sumbangan yang diberikan komitmen organisasi terhadap OCB adalah sebesar 15.1 persen, selebihnya 84.9 persen dipengaruhi oleh faktor lain yang tidak diteliti. Dari hasil penelitian ini menyimpulan bahwa hipotesis penelitian dapat diterima.
\end{abstract}

Kata Kunci: Organizational Citizenship Behavior, Komitmen Organisasi

\begin{abstract}
This study aims to find relationship between organizational commitment and organizational citizenship behavior (OCB). The hypothesis of this study states that there is a positive relationship between organizational commitment and organizational citizenship behavior (OCB). The subjects of this study were teachers in Methodist-2 private school Medan consisting of 110 subjects selected by using purposive sampling method. Data were obtained from a scale to measure organizational commitment and OCB. Analysis of the data used is Pearson Product Moment Correlation with SPSS 20.00 for Windows program. The results of this research showed a correlation of $0.388(p<0.05)$ and showed that there is a positive relationship between organizational commitment and organizational citizenship behavior. The results of this study indicate that the contributions made by the variable organizational commitment to the OCB was 15,1 percent and the remaining 84,9 percent is influenced by other factors that are not examined. From these results it is concluded that the hypothesis is acceptable.
\end{abstract}

Keywords: Organizational Citizenship Behavior, Organizational Commitment

How to Cite: J. Yustan, D. Atrizka, \& A.I.D. Putra (2019). Organizational Citizenship Behavior DItinjau dari Komitmen Organisasi pada Guru di Sekolah Swasta Methodist-2 Medan. Journal of Education, Humaniora and SocialSciences (JEHSS). 2 (1): 83 - 92. 


\section{PENDAHULUAN}

Pada umumnya manusia mempunyai banyak tujuan. Seringkali untuk mencapai tujuan tersebut, seseorang membutuhkan bantuan individu lain untuk diajak bekerja sama demi mencapai tujuan tersebut. Seiring dengan waktu dan perkembangan zaman, bentuk kerjasama tersebut berkembang ke arah yang lebih baik, sistematik, dan bertujuan sehingga tercipta adanya suatu wadah yang terorganisir, atau yang dikenal sekarang, yaitu organisasi (Weber, dalam Thoha, 2016).

Salah satu organisasi formal adalah sekolah. Sekolah adalah suatu Lembaga organisasi yang diberi kemampuan puntuk menyelenggarakan kegiatan belajar dan mengajar. Berdasarkan kehidupan di masyarakat sekolah termasuk dalam organisasi pendidikan. Organisasi pendidikan adalahorang-orang yang bersama dalam melaksanakan suatu tujuanobjektif dalam bidang pendidikan dan meningkatkan pengetahuan dalam hidup masyarakat (Hasbullah, 2006).

Dalam prosesnya, pendidikan sebagai bagian dari perjuangan kebudayaan di dalam membawa anak didik ke arah pengembangan diri menjadi pribadi yang sempurna akal budi, serta terampil dalam menyelenggarakan kehidupan yang memerlukan seperangkat alat untuk mencapai tujuan tersebut. Untuk mencapai tujuan dalam pendidikan tentu dibutuhkan guru untuk menjadi sumber daya manusia sebagai pelaksana pendidikan seperti mengejar target pencapaian kurikulum daripada melaksanakan konsepsi pendidikan berwawasan kebudayaan membangun karakter bangsa (Suyanto \& Djihad, 2013).

Guru sebagai pekerja harus berkemampuan, yang meliputi penguasaan materi, penguasaan profesi dan stabilitas menjalankan ketugasan pengembangan diri guru sesungguhnya. Guru pada prinsipnya memiliki kemampuan yang tinggi untuk berkreasi dalam meningkatkan kinerjanya. Guru dalam meningkatkan kinerjanya tidak selalu berkembang dengan baik disebabkan adanya pengaruh dari berbagai faktor yang dapat menyebabkan seorang guru tidak bekerja dengan efektif, maka untuk menjadi guru yang profesional dan mempunyai kinerja yang baik diperlukan perilaku yang baik dan berkualitas (Rochman \& Gunawan, 2016).

Bekerja melebihi standar yang diharapkan adalah salah satu perilaku yang sangat dibutuhkan oleh setiap organisasi karena dapat memberikan dampak yang baik bagi organisasi tersebut. OCB berkaitan dengan manifestasi seseorang sebagai mahluk sosial. 
Dengan kemampuan berempati seseorang mampu memahami orang lain dan lingkungannya serta bisa menyesuaikan nilai-nilai yang dianutnya dengan nilai-nilai yang dianut oleh lingkungannya (Oemar, 2011).

Berdasarkan hasil survei awal yang peneliti lakukan di Sekolah Swasta Methodist-2 Medan. Setelah dilakukan observasi dan wawancara pada para guru yang bekerja di sekolah tersebut, mengungkapkan bahwa ada beberapa guru yang sering terlambat masuk kelas. Mereka mengeluh apabila lembur, enggan menggantikan guru lain bila guru tersebut berhalangan untuk hadir. Mereka juga jarang ikut berpartisipasi sebagai panitia dalam setiap kegiatan atau acara di sekolah. Ada beberapa guru juga mengeluh ketika ada murid yang bertanya di luar jam mengajar. Mereka enggan membantu para murid yang belum mengerti dan tidak mau membantu para murid yang bukan merupakan murid kelasnya sendiri. Selain itu, beberapa guru tersebut hanya mau mengajar sesuai dengan jam mengajar yang dijanjikan dan memberikan bimbingan apabila ada permintaan dari pihak sekolah.

Hasil wawancara peneliti diperkuat dengan observasi yang didapatkan di lapangan. Beberapa guru di Sekolah Swasta Methodist-2 Medan mengungkapkan bahwa ada guru yang sering terlambat masuk kelas. Mereka mengeluh apabila lembur, enggan menggantikan guru lain bila guru tersebut berhalangan untuk hadir. Mereka juga jarang ikut berpartisipasi sebagai panitia dalam setiap kegiatan atau acara di sekolah. Beberapa guru juga mengeluh ketika ada murid yang bertanya di luar jam mengajar. Mereka enggan membantu para murid yang belum mengerti dan tidak mau membantu para murid yang bukan merupakan murid kelasnya sendiri. Selain itu, beberapa guru tersebut hanya mau mengajar sesuai dengan jam mengajar yang dijanjikan dan memberikan bimbingan apabila ada permintaan dari pihak sekolah.

Organisasi yang sukses membutuhkan pekerja yang melakukan kinerja di atas harapan. Organisasi menginginkan dan membutuhkan pekerja yang akan melakukan pekerjaan yang tidak dalam deskripsi pekerjaan. Menurut Smith (dalam Titisari, 2014), OCB merupakan kontribusi pekerja di atas dan lebih dari deskripsi kerja formal. Titisari (2014) mengungkapkan bahwa OCB membantu mengubah keadaan organisasi yang formalmenjadi sedikit santai dan penuh dengan kerja sama, diharapkan dengan suasana yang seperti itu maka ketegangan diantara para karyawan dapat dikurangi dan karena 
suasana yang mendukung diharapkan produktivitas karyawan meningkat, sehingga akan tercapai keefektifan dan keefisienan dalam mencapai tujuan organisasi.

Pernyataan tersebut juga dibenarkan oleh Smith (dalam Titisari, 2014) yang berpendapat bahwa OCB dapat melicinkan dan melancarkan kehidupan sosial dalam suatu organisasi. OCB merupakan kinerja kontekstual merujuk pada perilaku-perilaku yangsecara formal bukan bagian dari deskripsi kerjanya, yang merupakan perilakuperilaku yang lebih berkaitan dengan unsur-unsur sosial dalam tempat kerja dibandingkan dengan unsur-unsur tugas (Levy, 2009).

Komitmen organisasional mempunyai pengaruh yang menentukanpilihan pekerja tetap tinggal sebagai anggota organisasi atau meninggalkan organisasi mencari pekerjaan baru. Selain itu komitmen yang tinggi juga akan berdampak pada peningkatan karir karyawan itu sendiri. Pada umumnya organisasi akan memberikan imbalan kepada karyawan atas pengorbanan yang telah diberikan kepada organisasi (Biggart \& Hamilton, dalam Sophia, 2008). Bila komitmen tinggi maka karyawan akan lebih puas dalam kehidupan mereka secara keseluruhan. Koontz (dalam Titisari, 2014) menyatakan OCB merupakan perilaku positif karyawan yang mendorong tercapainyatujuan dari perusahaan dan sangat penting dalam menentukan apakah perusahaan tersebut berhasil atau tidak. Dalam hal ini Luthans (2006) jelas mengemukakan bahwa komitmen organisasi jelas berhubungan dengan OCB.

Komitmen organisasi (Sophia, 2008) adalah suatu ikatan psikologis karyawan pada organisasi yang dimana adanya kepercayaan dan penerimaan atas tujuan dan nilai-nilai organisasi,tercapainya kepentingan organisasi, dan keinginan untuk tetap bertahan sebagai anggota organisasi. Besarnya komitmen organisasi seorang pekerja tentu sangat mempengaruhi banyaknya perilaku OCB yang dimunculkannya. Pada salah satu penelitian terdahulu yang dilakukan oleh Ristiana (2013) terhadap 112 pegawai negeri sipil (PNS) di Rumah Sakit Bhayangkara Trijata Denpasar menunjukkan hasil bahwa komitmen organisasi berkorelasi positif dengan OCB artinya, ketika karyawan mempunyaikomitmen organisasi yang tinggi maka OCB juga akan tinggi dan sebaliknya ketika karyawan mempunyai komitmen yang rendah maka OCB juga akan rendah.

OCB merupakan perilaku yang harus dimilikioleh setiap guru untuk mampu bekerja melebihi deskripsi kerjanya. Guru dituntut mempunyai kinerja yang dapat mewujudkan 
harapan dan keinginan semua pihak, terutama masyarakat umum. Tuntutan yang besar itulah yang akan mempengaruhi komitmen yang akan diberikan pada organisasinya.

Penelitian terdahulu oleh Rini, dkk., (2013) menyatakan bahwa komitmen organisasi memiliki hubungan positif dengan OCB terhadap 143 karyawan di PT. PlasaSimpangLima. Karyawan yang merasa puas terhadap pekerjaannya akan bekerja maksimal dalam menyelesaikan pekerjaannya dan secara sukarela bekerja melebihi tugasnya. Berbagai studi yang telah dilakukan menunjukkan orang dengan komitmen organisasi yang tinggi akan merasa puas dalam bekerja dan rela berbuat untuk kemajuan perusahaannya.

Berdasarkan uraian di atas dengan kurangnya kesadaran para guru atas pekerjaannya dalam memberikan kontribusi yang lebih bagi sekolah, maka peneliti tertarik untuk mengaitkan untuk meneliti hubungan antara komitmen organisasi dengan OCB terhadap guru di sekolah swasta Methodist-2Medan. Adapun yang membedakan penelitian ini dengan penelitian terdahulu adalah subjek penelitian yaitu seluruh guru di sekolah swasta Methodist-2 mulai dari tingkat PG, TK, SD, SMP dan SMA. Penelitian ini bertujuan untuk mengetahui hubungan antara komitmen organisasi dengan OCB.

Manfaat praktis yang diharapkan dari penelitian ini jika hipotesis diterima adalah dapat menjadi masukan yang berguna bagi para guru agar dapat terus memberikan kontribusinya yang lebih baik dalam organisasi sekolah. Hipotesis dalam penelitian ini adalah ada hubungan yang positif antara komitmen organisasi dengan OCB.

\section{METODE PENELITIAN}

Desain penelitian yang digunakan adalah penelitian kuantitatif dengan teknik analisis data korelasional. Penelitian korelasional sebagai teknik pengelolaan data dengan caramenghubungkan dua variabel atau lebih untuk mengetahui tingkat keeratan hubungan (Siswanto, Susila, \& Suyanto, 2017). Penelitian ini menggunakan teknik pengujian korelasi Pearson Product Moment untuk melihat hubungan variabel bebas dengan variabel terikat.

Populasi dalam penelitian ini adalah seluruh guru di sekolah swasta Methodist-2 Medan yang berjumlah 160 orang. Penelitian ini melibatkan 110 guru sekolah swasta Methodist-2 yang dipilih dengan teknik purposive sampling dengan kriteria merupakan 
guru yang mengajar mulai dari tingkat PG, TK, SD, SMP dan SMA dan dengan jabatan sebagai wali kelas, guru asisten ataupun guru mata pelajaran.

Metode skala Likert merupakan alat pengumpul data yang dilakukan dalam penelitian ini. Skala OCB dikembangkan peneliti berdasarkan dimensi-dimensi yang dipaparkan oleh Organ (dalam Yuniar, dkk) yang meliputi dimensi altruism, courtesy, sportsmanship, conscientiousness dan civicvirtue. Total aitem untuk skala OCB sebanyak 50 aitem yang terdiri dari masing-masing 10 aitem untuk dimensi altruism, courtesy, sportsmanship, conscientiousness dan civic virtue.

Skala komitmen organisasi dikembangkan peneliti berdasarkan dimensi-dimensi yang dipaparkan oleh Meyer dan Allen (dalam Ristiana, 2013) yang meliputi dimensi komitmen afektif (affective commitment), komitmen berkelanjutan (continuance commitment) dan komitmen normatif (normative commitment). Total aitem untuk skala komitmen organisasi sebanyak 36 aitem yang terdiri dari masing-masing 12 aitem untuk dimensi komitmen afektif (affective commitment), komitmen berkelanjutan (continuance commitment) dan komitmen normatif (normative commitment). Skala OCB komitmen organisasi yang sudah diisi dilanjutkan dan melakukan penilaian pada masing-masing pilihan jawaban subjek. Skor nilai kemudian diuji validitasnya dengan program SPSS versi 20.00 for windows.

Sebelum pengambilan data penelitian, peneliti melaksanakan try out terlebihdahulu terhadap 67 subjek guru yang sesuai dengan karakteristik yang ditetapkan pada subjek penelitian di Yayasan Perguruan Sriwijaya Jalan Bridjend. Zein. Hamid Gg. Pembangunan N0. 25 Medan sekolah swasta Methodist-2 Medan Jalan M.H. Thamrin No. 96 di Kota Medan. Setelah dilakukan try out, hasil uji coba skala dijelaskan di bawah ini.

Hasil uji validitas terhadap Skala OCB ini menunjukkan nilai rix bergerak dari 0,301 hingga 0,676 sehingga sebanyak 23 aitem dinyatakan gugur. Total aitem yang digunakan dalam penelitian ini sebanyak 27 aitem untuk mengukur OCB pada subjek penelitian.

Reliabilitas Skala OCB ini diuji dengan teknik Alpha Cronbach yang menunjukkan hasil $\alpha=0,891$. Sehingga, dapat disimpulkan Skala OCB ini sudah reliabel karena sudah memenuhi koefisien reliabilitas yang baik, yaitu di atas 0,6 (Sugiyono, 2013). Hasil uji validitas terhadap skala komitmen organisasi ini menunjukkan nilai rix bergerak dari 0,323 hingga 0,573 sehingga sebanyak 11 item dinyatakan gugur. Total item yang digunakan dalam penelitian ini sebanyak 25 item untuk mengukur komitmen organisasi 
pada subjek penelitian. Reliabilitas skala komitmen organisasi ini diuji dengan teknik Alpha Cronbach yang menunjukkan hasil $\alpha=0,865$. Sehingga, dapat disimpulkan skala komitmen organisasi ini sudah reliabel karena sudah memenuhi koefisien reliabilitas yang baik, yaitu di atas 0,6 (Sugiyono,2013).

Setelah mendapatkan hasil uji validitas dan reliabilitas yang baik, peneliti kemudian menyebarkan angket kepada 110 guru yang menjadi subjek dalam penelitian ini. Setelah data terkumpul, selanjutnya peneliti melakukan pengolahan data dan uji hipotesis dengan Pearson Product Moment Correlation. Hasil Pearson Product Moment Correlation dapat dikatakan tidak menyimpang apabila memenuhi syarat uji asumsi klasik data yang mana mensyaratkkan data harus terdistribusi normal dan memiliki hubungan linear antar variabel yang diteliti (Hadi, dalam Siswanto, dkk., 2017). Berdasarkan hasil analisis, ditemukan bahwa semua syarat untuk menggunakan teknik Pearson Product Moment Correlation terpenuhi, yaitu data terdistribusi normal dan kedua variabel memiliki hubungan yang linear.

\section{HASIL DAN PEMBAHASAN}

Berdasarkan data di atas, untuk variabel OCB, terdapat 0 subjek (0 persen) yang memiliki OCB rendah, terdapat 25 subjek (22,7 persen) yang memiliki OCB sedang, dan terdapat 85 subjek (77,3 persen) yang memiliki OCB tinggi. Berdasarkan penjelasan diatas maka dapat ditarik disimpulkan bahwa rata-rata subjek penelitian memiliki perilaku OCB yang tinggi.

Dari skala OCB yang diisi subjek, maka diperoleh mean empirik sebesar 5.073 dengan standar deviasi 5.073. Apabila mean empirik > mean hipotetik maka hasil penelitian yang diperoleh akan dinyatakan tinggi dan sebaliknya jika mean empirik < mean hipotetik maka hasil penelitian akan dinyatakan rendah. Hasil analisis untuk skala OCB diperoleh mean empirik > mean hipotetik yaitu 84.03>67.5 maka dapat disimpulkan bahwa OCB pada subjek penelitian lebih tinggi daripada populasi pada umumnya.

Selanjutnya, untuk hasil kategorisasi variabel komitmen organisasi dari jumlah subjek 110 guru menunjukkan bahwa tidak ada subjek ( 0 persen) yang memiliki komitmen rendah, terdapat 110 subjek (110 persen) yang memiliki komitmen sedang, dan terdapat 0 subjek ( 0 persen) yang memiliki komitmen tinggi. Berdasarkan 
penjelasan tersebut maka dapat disimpulkan bahwa rata-rata subjek penelitian memiliki komitmen organisasi sedang.

Dari skala komitmen organisasi yang diisi subjek, maka diperoleh mean empirik sebesar 81.37 dengan standar deviasi 5.001. Apabila mean empirik > mean hipotetik maka hasil penelitian yang diperoleh akan dinyatakan tinggi dan sebaliknya jika mean empirik < mean hipotetik maka hasil penelitian akan dinyatakan rendah. Hasil analisis untuk skala komitmen organisasi diperoleh mean empirik > mean hipotetik yaitu 81.37>62.5 maka dapat disimpulkan bahwa komitmen organisasi pada subjek penelitian lebih tinggi daripada populasi pada umumnya.

Hasil uji normalitas sebaran dilakukan agar dapat mengetahui apakah setiap variabel penelitian telah terdistribusi secara normal atau tidak. Uji normalitas sebaran dalam penelitian ini menggunakan uji Kolmogorov. Data dinyatakan terdistribusi normal jika p>0.05 (Priyatno, 2011). Berdasarkan hasil uji normalitas sebaran, dapat diketahui uji normalitas sebaran pada variabel OCB diperoleh koefisien sig 1 (satu) arah dari variabel OCB sebesar 0.1005 ( $p>0.05$ ), yang berarti bahwa data pada variabel OCB memiliki sebaran atau terdistribusi normal. Uji normalitas sebaran yang dilakukan terhadap variabel komitmen organisasi diperoleh koefisien sig uji 1 (satu) arah dari variabel komitmen organisasi sebesar 0.229 ( $p>0.05$ ), yang berarti bahwa data pada variabel komitmen organisasi memiliki sebaran atau terdistribusi normal.

Uji linearitas hubungan dimaksudkan untuk mengetahui derajat hubungan antara variabel bebas dengan variabel terikat dalam penelitian ini, yaitu OCB dan komitmen organisasi, sebagai syarat dilakukannya pengujian analisis data korelasional Pearson Product Moment dengan tujuan untuk melihat apakah kedua variabel tersebut memiliki hubungan yang linear atau tidak. Sebagai kriterianya apabila nilai signifikansi $<0,05$ maka dinyatakan memiliki derajat hubungan yang linear. Berdasarkan hasil pada hasil pengujian linearitas, dapat dilihat nilai sig sebesar 0.000 yang mana $p<0.05$, sehingga dapat disimpulkan bahwa kedua variabel memiliki hubungan linear dan dilanjutkan dengan analisis Pearson Product Moment Correlation.

Berdasarkan hasil uji hipotesis dengan teknik Pearson Product Moment Correlation menunjukkan bahwa terdapat hubungan positif antara OCB dengan komitmen organisasi $(r=-0.388, p=0.000<0.05)$. Hal ini menunjukkan bahwa adanya korelasi positif antara OCB dengan komitmen organisasi (Priyatno, 2011). Dari hasil perhitungan 
tersebut, maka hipotesis dalam penelitian ini menunjukkan ada hubungan positif antara OCB dengan komitmen organisasi pada guru di sekolah swasta Methodist-2 Medan dapat diterima.Dalam penelitian ini diperoleh koefisien determinasi $\left(\mathrm{R}^{2}\right)$ sebesar 0.151 . Variabel komitmen organisasi memberikan sumbangan 15.1 persen terhadap variabel OCB dan selebihnyasebesar 84.9 persen dipengaruhi oleh penyebab-penyabab lain yang tidak diteliti pada penelitian ini, seperti kepribadian, kepemimpinan, iklim organisasi, kepuasan kerja, kecerdasan emosional, persepsi dukungan organisasi (perceived organizational support), budaya organisasi, kualitas kehidupan kerja (quality of work life), motivasi kerja, psychological capital, kontrak kerja (work engagement) dan kebahagiaan di tempat kerja(happiness at work).

\section{SIMPULAN}

Penelitian ini menunjukkan adanya hubungan antara komitmen organisasi dengan OCB pada guru di Sekolah Swasta Methodist-2 Medan. Berdasarkan hasil-hasil yang telah diperoleh dalam penelitian ini, maka dapat disimpulkan hipotesis penelitian ini menunjukkan ada hubunganpositif antara komitmen organisasi dengan OCB dengan jumlah subjek sebanyak 110 orang. Hasil dari korelasi sebesar 0,388 dan dengan $\mathrm{p}=0.000(\mathrm{p}<0.05)$, dan nilai $\mathrm{R}$ square $\left(\mathrm{R}^{2}\right)=0,151$. Kesimpulan dari penelitian ini semakin tinggi komitmen organisasi yang dimiliki guru yang bekerja di sekolah swasta Methodist-2 Medan maka semakin tinggi OCB yang mereka munculkan dan sebaliknya.

\section{DAFTAR PUSTAKA}

Hasbullah. (2006). Dasar-dasar Ilmu Pendidikan. Jakarta: PT Raja Grafindo Persada.

Luthans, F. (2006). Perilaku Organisasi Edisi 10. Yogyakarta: Andi.

Levy. P. E. 2009. Industrial Organizational Psychology; Understanding The Workplace (3rdEd). New York: Worth Publishers.

Oemar, Y. (2013). Pengaruh Budaya Organisasi, Kemampuan Kerja dan Komitmen Organisasi terhadap Organizational Citizenship Behaviour (OCB) Pegawai pada Bappeda Kota Pekanbaru. Jurnal AplikasiManajemen Maret 2013, 11(1): 65-76.

Purba, D. E., \& Seniati, A. N. (2004). Pengaruh Kepribadian dan Komitmen Organisasi Terhadap Organizational Citizenship Behavior. Makara Sosial Humaniora, 8(3): 105-111.

Priyatno, D. (2011). Teknik Mudah dan Cepat Melakukan Analisis Data Penelitian dengan SPSS. Yogyakarta: Gaya Media.

Rini, D. P., Rusdarti \& Suparjo. 2013. Pengaruh Komitmen Organisasi, Kepuasan Kerja dan Budaya Organisasi terhadap Organizational Citizenship Behavior (OCB) pada PT. Plasa Simpanglima Semarang. Jurnal Ilmiah Dinamika Ekonomi dan Bisnis, 1(1): 69-88.

Ristiana, M. (2013). Pengaruh Komitmen Organisasi dan Kepuasan Kerjaterhadap Organizational Citizenship Behavior (OCB) dan Kinerja Karyawan Rumah Sakit Bhayangkara Trijata Denpasar. Jurnal Ilmu Ekonomi dan Manajemen, 3(1): 56-70. 
Rochman, C., \& Gunawan, H. (2016). Pengembangan Kompetensi Kepribadian Guru. Bandung: Nuansa.

Siswanto, Susila, \& Suyanto. (2017). Metodologi Penelitian Kombinasi Kualitatif Kuantitatif Kedokteran dan Kesehatan. Klaten: Bossscript.

Sophia. (2008). Perilaku Organisasional. Yogyakarta: Andi.

Sugiyono. (2013). Pebelitian Pendidikan. Bandung: Alfabeta.

Sutrisno, E. (2010). Budaya Organisasi. Jakarta: Kencana.

Suyanto, \& Djihad, A. (2013). Bagaimana Menjadi Calon Guru \& Guru Profesional. Yogyakarta: Multi Pressindo.

Thoha, M. (2016). Perilaku Organisasi: Konsep Dasar \& Aplikasinya. Jakarta: PT Raja Grafindo Persada. 